\title{
Flooding and post flooding response strategies in Ghana
}

\author{
D. K. Ahadzie ${ }^{1}$ \& D. G. Proverbs ${ }^{2}$ \\ ${ }^{1}$ Centre for Settlements Studies, Institute of Human Settlements Research, \\ College of Architecture and Planning, \\ Kwame Nkrumah University of Science and Technology, Ghana \\ ${ }^{2}$ School of Engineering and the Built Environment, \\ University of Wolverhampton, UK
}

\begin{abstract}
Flooding is an inevitable phenomenon but in recent years the flooding of major cities and conurbations has been the cause of disasters on an unprecedented scale. In this respect, a most critical issue for all cities whether developing or developed is to be fully prepared in their response towards mitigating the worst effects should flooding occur. This demands a full understanding of the recurring challenges that confront cities especially those in developing countries where institutional capacity is weak. Using the qualitative technique of content analysis, the management and structural themes emerging from Ghanaian newspapers in respect of flood recovery, innovations and response for the last five years are identified, analyzed and reported. Evidence induced will help international players of the flood recovery agenda appreciate the preparedness of "typical" developing countries such as Ghana in the global attempt towards effective management to mitigate the worst effects of this act of God. To this extent, the findings could be useful towards searching for an international framework for influencing policy decisions in respect to flood recovery and response in developing countries such as Ghana.
\end{abstract}

Keywords: content analysis, flood response, Ghana, West Africa.

\section{Introduction}

Ghana lies in the West Africa Sub-region a few miles north of the Equator, and as with many West African Countries, rainfall is noted to be the most important 
element of the climate (Bunnett and Okunrotifa [1].) Within this context of rainfall, Ghana like many other countries in the sub-region are also potentially prone to flooding which unfortunately often wreaks havoc. Indeed, in Ghana in particular, the print and electronic media has within the last 10 years amply exposed flooding of some cities and townships, especially bringing to bear some catastrophic moments. For instance in 2005, The Ghanaian Times [2] (June 9, page 6) reported that "Part of Saltpond, the capital of Mfantseman District got flooded on Tuesday as a result of heavy downpour destroying property worth million of cedis". The banner headline preceding the foregoing indicated this was the worst flooding in the Saltpond township for 20 years. Similarly the Ghanaian Times [3] (June 23 2005, page 7) reported that: " Most parts of Kasoa especially the Kasoa New Road were flooded at the weekend following torrential rains that lasted the whole day......For the residents of Kasoa-New Town the Situation compelled them to lock themselves indoors for fear of being drowned by the floods".

In June 2007, the Daily Graphic [4] $\left(2^{\text {nd }}\right.$ June, page 1$)$ confirmed 7 people dead and hundreds of residents forced out of their houses in Accra the capital. The following year in August 2008, The Daily Graphic [5] in one of its editions confirmed 4 people dead and 150 rendered homeless also in Accra the capital city. Indeed numerous devastating effects of flooding across many cities and townships in Ghana could be recounted from the mass-media. Contextually, the worst effect is recorded in September 2007. Here, a source attributed to United Nations Office for the coordination of Humanitarian Affairs (UNOCHA) [6] reported that: "Flooding in Upper East, Upper West and Northern regions has killed 20 people and affected 260,000 according to the Government. Victims are spread as follows: Upper east 30 affected and 20 deaths; Northern region 227817 affected and eight deaths and Upper West 250 affected and four deaths."(www.ghanahomepage, accessed 12/16/2009) [7].

Adding up the casualties from the regions indicates that the death toll was actually 32 . In view of the magnitude of the floods, the Government of Ghana declared a state of emergency in the three affected regions. What is clear from the foregoing is that, floods in Ghana have been wreaking havoc for some considerable time and evidence suggests the situation is getting worse. The flooding of cities is an unavoidable international phenomenon that is gaining reputation for causing disasters. However, there is no doubt that, having a better understanding of the causes of the worst effect of flooding and also the response strategies that can offer effective management control, the worst effect including those relating to socio-economic could be better minimized. Concomitantly, in Ghana for instance while a lot of debate has often gone on how to best address the aftermaths of flooding, an analytical situation involving a full understanding of the recurring challenges that confront in achieving effective direction for flood recovery, innovations and response is lacking. Here, content analysis is used to establish the emergent themes for understanding the Ghanaian situation.

First, a brief geographical summary of Ghana is provided. This is then followed by highlights of flooding especially the management and policy issues available to dealing with their worst effects. Thereafter, commentary is provided 
on the philosophy underlying content analysis as used in the paper. The research design is then described including data collection procedures. Next is the findings and finally the paper concludes with recommendation for the way forward.

\section{Brief geographical information on Ghana}

Ghana (Figure 1) is located on West Africa's Gulf of Guinea only a few degrees North of the Equator. Half of the country lies less than 152 metres (500ft) above sea level and the highest point is 883 metres (2900ft). It has a 737 Kilometre coastline of low sandy shore backed by plains and scrub and intersected by several rivers and streams, most of which are navigable only by canoe. Two distinct rainy seasons prevails. In the South this occurs in May-June and then August September while in the North the season tend to merge to AugustSeptember. The period between January and February is usually dry following dry northeasterly harmattan wind.

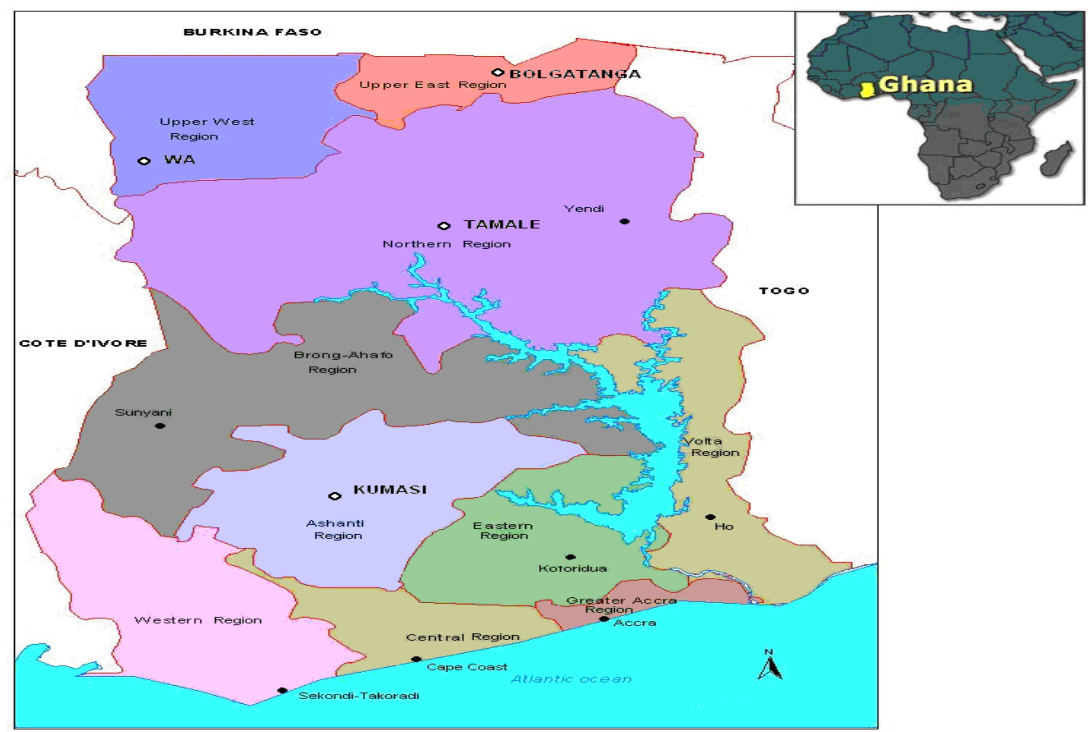

Source: www.Ghanaweb.com cited in Ahadzie [8].

Figure 1: Map of Ghana showing position in relation to West Africa Neighbours.

Generally similarities exist across the sub-region on the rainfall effect (Bunnett and Okunrotifa [1].) To this effect, the amount of rainfall, where and when it falls largely depends on the interaction of the tropical continental and maritime masses. Indeed, according to Bunnett and Okunrotifa [1], the heaviest rainfall occurs in the South and along the coast, to the extent that, during the Northern summer the whole of the West Africa as far as 2 degrees north comes 
under rain bearing south west monsoon. Annual rainfall in the coastal zone of Ghana averages 83 centimetres.

\section{Management of flooding}

The Meteorological Services Department of Ghana is responsible for keeping climatic and rainfall data in Ghana. While the Meteorological Department obviously do keep some data on the rainfall pattern in Ghana, it is not quite clear whether they do have any robust data on the history of flooding. This is buttressed by the point that efforts to establish records of the history of flooding in Ghana proved futile. Subsequently while the paper focus on flooding issues recorded in the newspapers within the last decade, it is not clear what data set the Meteorological Department might be keeping in their archives. However, it is worth mentioning that even though the paper addresses flooding of recent times, there is some evidence to indicate that flooding has almost always been part of Ghana and the effects are not good to write about. For example, it is reported that in 1995 about 26 people died as a result of flooding in Accra alone (Kwarteng [9]). In another revelation, Kwarteng [9] noted that, 65 people were declared dead in Accra following severe flooding in 1999. Again in 2001, about 21 people were reported dead from floods in the Accra Metropolis [9].

The National Disaster Management Organization (NAMDO) is responsible for managing the effects of all disasters including flooding in Ghana. Among others, the NADMO is to perform the following functions:

- Coordinate the activities of various bodies in the management of disasters

- Rehabilitate persons affected by disasters

- Mobilize affected communities to support various Government programmes, such as poverty reduction programme as well as those aimed at the management of disasters

- Ensure that the country is prepared to prevent disasters and manage them well when they occur

Thus, in principle the NADMO is to be at the forefront in sensitizing and educating Ghanaians on what and what not to do in the event of a disaster like flooding. Further they are responsible for mobilizing resources to be distributed as relief items often to affected victims. To this extent the NADMO have offices located at the national, district and zonal levels to help facilitate their activities. While it could be argued that the NADMO is doing its possible best especially regarding offering relief items to potential victims as and when necessary and within their means, very little is known of any activities regarding education of Ghanaians on what to do pre and post flooding. The net effect is that, many Ghanaians are just ignorant of any innovations and post flooding response strategies that can meaningfully help potential victims of flooding to make inform choices at such critical moments. A case in point is the reference made on page 2 regarding flooding of the Kasoa Township in June 2005 [3]. It is noted that for the residents, their immediate reaction was to lock themselves indoors for fear of being drowned. As to whether this was the right thing to do at such a 
moment can be contested, however all indications point to the fact that the residents chose that option because it was the easiest thing to do based on common sense and not that they have been properly educated (cf. Kwarteng [9]). The content analysis provide further evidence that there is much to be done to test the readiness and preparedness of designated Ghanaian agencies in flood recovery, innovations and response.

\section{The content analysis}

Content analysis is a detailed and systematic examination of the contents of a particular body of material for the purpose of identifying, patterns, themes or biases (Leedy and Ormrod [10]). Content analyses are typically performed on forms of human communication including books, newspapers, films, television, art, music videotapes of human interaction and transcript of conversations. As a general rule, where the researcher is dealing with a small body of knowledge, then it might be advisable to sample the entire body. Alternatively, if the researcher is faced with a large volume of data spanning number of years, a sample (perhaps random sampling) is selected. Almost invariably, one crucial step in content analysis is to tabulate the frequency of each characteristics found in the material being studied, Thus content analysis is quantitative as well qualitative. Thus content analysis tend to focus at a more micro level often providing frequency counts and allow for quantitative analysis of qualitative data.

Themes within data can be identified in one of two major ways in content analysis; inductive or deductive (cf. Braun and Clarke [11]). Inductive approach presumes that themes identified are strongly linked to the data themselves (Pattton [12] cited in Braun and Clarke [11]). In contrast, the deductive approach is driven by the researchers' theoretical or analytic interest. It is however to be noted that notwithstanding these choice of the inductive approach, researchers cannot free themselves from their theoretical and epistemological inclinations. Thus, whether the choice is inductive or deductive; the data would almost always be coded in some epistemological setting (cf. Braun and Clarke [11]).

\section{Data collection and analysis}

The data was culled from Daily Graphic and Ghanaian Times [13-56], the two most popular state newspapers. The focus was on these newspapers because of their wide circulation, making more likely for flood related issues to be reported from all parts of the country. A total of 47 papers were read, the break down being 10 for 2009, 8 for 2008, 21 for 2007, 4 for 2006 and 4 for 2005. The newspapers are kept in the archives of the Centre for Settlements Studies of the Kwame Nkrumah University and Science and Technology. With knowledge of the rainfall pattern in Ghana the papers were scanned through and particularly papers circulated in June and September were selected. Here, the authors went into the study largely with no prior theoretical frameworks, hence the themes that emerged came directly from the articles in the papers. That is in this case the 
coding was data-driven but not the researchers theoretical interest. However, as noted earlier, coding of data in content analysis cannot be done in a somewhat theoretical vacuum. To this effect, Strahler and Strahler [55] framework on the causes and effects of floods, flood prediction, flash points and education have useful here.

Table 1: $\quad$ Content analysis of Ghanaian Newspapers from 2005-2009.

\begin{tabular}{|c|c|c|c|}
\hline Action & Count & Percentage & Remark \\
\hline Prediction & 3 & $6.38 \%$ & $\begin{array}{c}\text { Largely linked to the } \\
\text { Bagre Dam alert and not } \\
\text { general flooding. The } \\
\text { floodgates to the Bagre } \\
\text { Dam in Burkina Faso. } \\
\text { The effect of the spillage } \\
\text { in northern Ghana would } \\
\text { be felt after 24 hours }\end{array}$ \\
\hline Relief items & 17 & $36.17 \%$ & \\
\hline Causes & 5 & $10.64 \%$ & \\
\hline Education & 0 & $0 \%$ & \\
\hline Effect & 19 & $40.43 \%$ & \\
\hline Rescue & 3 & $6.38 \%$ & $\begin{array}{c}\text { A rapid response team } \\
\text { comprising the Nadmo. } \\
\text { This reportage is linked to } \\
\text { the Bagre Dam alert }\end{array}$ \\
\hline Totals & & & \\
\hline & 47 & $100 \%$ & \\
\hline
\end{tabular}

First a quick scan was done to familiarize the authors with typical issues emerging. This helped to form an initial view of the kind of themes to be looking for. Following various readings, the following keywords; prediction, relief items, causes, response strategies, international response and education initially emerged. However, subsequent and detailed readings revealed that, some of the themes could be merged as they were invariably addressing the same issue. In the end, the following themes thus emerged predominant, coded and transferred into quantitative data (Table 1).

Table 1 represents the findings of the analysis. The evidence indicates that during the period under review, $10.64 \%$ of Ghanaian reportage focused on the causes of flooding, presumably after the flooding has occurred, $40.43 \%$ of reportage centered on the effects of the flooding while $36.17 \%$ reportage was on the provision of relief items. Whereas $6.38 \%$ reportage focused on prediction and rescue missions, not a single reportage was observed on education.

\section{Discussion of results}

The content analysis has revealed that, in the last five years the Ghanaian massmedia has carried enough information on the occurrence of floods and the ensuing havoc it can cause from its explosive powers. In a developing country such as Ghana, it is not surprising that the response strategy as indicated in the analysis favoured reportage on the effects of flooding and the provision of relief 
items. Natural disasters as they are, flooding demands that politicians quickly visits such places to show solidarity to potential victims and in most cases relief items is the obvious thing to do to win sympathies. With politicians in attendance the national press also needs to give enough coverage including emphasizing on the effects of the flooding. Thus it makes political as well as socio-economic sense that relief items and effects appears to reflect heavily in the content analysis.

Obviously, while the rapid response to issuing relief items is crucial and very much welcome in such disasters, it is also true that having a better understanding of flooding and its prediction can help one better prepare and perhaps minimize the prevalence of flood damages. However in Ghana, the findings have revealed that very little or no strategy is in place to predict and warn victims of a potential flooding. Here, $6.38 \%$ reportage reflected prediction. Specifically, out of the 47 papers reviewed in the last five years, two newspapers reported prediction in relation to the Bagre Dam (see Table 1) alert in neighbouring Burkina Faso whilst only one newspaper reported prediction relating to general flood alert. This flood alert issued by the meteorological services department (Daily Graphic April 3, 2008, page 1 [29]) read that; "Severe floods will hit parts of Accra between now and August as a result of unusually heavy rains expected in the southern parts of the country". In a related issue, Daily Graphic [30] (April 4, 2008) reported that "A rapid response team has been formed by the NADMO to undertake emergency operations in line with the severe flooding which is predicted to hits certain part of Accra. Whilst this prediction effort is in the right direction towards effective flood management, it also appears to be very general indeed and not targeted towards any specific prediction flash points useful for effective community flood management strategy. Ideally one would also have expected the prediction to cover specific water courses and river banks which are likely to overflow and make the flooding severe.

That is, there is a clear lack of mapping out strategy towards addressing flood prediction at specific locations. This lack of prediction system in the Ghanaian context (a developing country) is in contrast with many developed economies where emphasis on prediction counts amongst one of the critical response strategies. For instance in some part of the US (cf. Strahler and Strahler [55]) it is noted that the national weather service provides a flood warning service and this national weather service operates a river and flood forecasting service through 85 offices located at strategic points along major river streams. Each office issues river and flow forecast to the communities. Such systematic and conscious attempt to flood response strategy is clearly missing in the Ghanaian context, at least as demonstrated in the analysis. Thus, apart from the specific case linked to the floodgates of the Bagre Dam in Burkina Faso, the analysis indicates that there has not been any systematic reportage relating to prediction strategy in flood control and response in Ghana. This suggests that Ghana has no systematic prediction strategy as part of its flood response and innovation strategies. It is also interesting to note that, the $6.38 \%$ reported on rescue mission was also directly linked to the Bagre Dam effect. 
Indeed in many other western countries, as part of the prediction strategies, rivers that are characterized by floods are often managed by defences such as levees bund, reservoirs and weirs to prevent rivers from bursting their banks, however, here in Ghana there is no indication of any such systems as evidenced in the reportage. The Global trend suggests that flooding is a threat to many human settlements and indeed is likely to be a major concern in the future especially in countries like Ghana where high population growth rate is compounded with uncontrollable physical development. It is therefore quite frightening that with all the potential of flooding becoming severe, response strategies relating to flood prediction is yet to be given a critical thought.

What is also very revealing in the content analysis is the lack of attention to public education on what to do in the event of flooding. Although one of the key functions of the NADMO is to ensure the country is prepared to prevent and manage disasters, it is interesting that the analysis has revealed virtually nothing on education to the public on what to do and what not to do in the event of flooding. Here it could be argued that apart from being called upon to organize and issue relief items indications are that the NADMO is not equipped to manage flooding. Indeed very little is heard of the NADMO on issues relating to seminars, educational programmes on TV and radio relating to flood management drills and flood evacuation drills. It is therefore not surprising not a single reportage was established from the two state newspapers reviewed. Here, the conclusion one can draw from this is, there is perhaps no educational policy and strategies in place to sensitize potential victims on flooding and post flooding events. Obviously a well established prediction system would no doubt provide robust basis for putting in place a good educational and information dissemination policy.

As noted by Bunnett and Okunrotifa [1], rainfall is the most important element of the climate in the West African sub-region. Similarly the potential for flooding also exists although this depends on the amount of rainfall, where and when it falls. Indeed the 2007 flooding which have been characterized as the worst effect in recent times is a manifestation of how serious the threat of flooding is to the sub-region. In this flood, almost 600,000 were reported to have been affected across about eight countries in the sub-region (UNOCHA $[6,58]$ ). Inevitable, the UNOCHA and other international donors have a role to play in such unprecedented levels of flooding. Based on the findings revealed, one area where the international community could assist is to help developing countries such as Ghana redirect focus towards improving prediction systems and also formulating pragmatic educational policies.

\section{Conclusion}

Flooding is recently gaining notorious attention as a perennial episode wreaking havoc in many developing countries such as Ghana. Using content analysis the emerging themes from Ghanaian newspapers over the last 5 years have been identified and analyzed. The evidence suggests while Ghana in principle has some system in place for granting at least some relief items to affected people, 
there is virtually nothing on prediction strategies and educational guidelines for the populace to act on. Given the international dimension that the effects of flooding can attract, it is suggested that major players such as UNOCHA should push for developing countries such as Ghana to push for predictions systems and education on flooding drills and evacuation strategies.

\section{Acknowledgements}

The authors wish to thank Ms Judith Mommo Derry and Amos Yesutanbul Nkpeebo, both National Service Persons at the Centre for Settlements Studies for retrieving the reviewed newspapers.

\section{References}

[1] Bunnett, R.B and Okunrotifa, General Geography in Diagrams for West Africa, Longman, 1984

[2] Ghanaian Times, Saltpond Gets Worse Floods in 20 Years. June 9, pp. 6/7, 2005

[3] Ghanaian Times, Kasoa Flooded June 23, pp. 7, 2007

[4] Daily Graphic, 7 people dead and hundreds forced out of residents, 2 June, pp.1, 2007

[5] Daily Graphic, Four Perish in Floods- 150 Others Rendered Homeless Aug. 22 pp. 1,3, 2008

[6] United Nations Office for the Coordination of Humanitarian Affairs (UNOCHA), Situation Report on Floods in Ghana (www.Ghanaweb.com, accessed, 12/16/2009, 2007

[7] Ghana Embassy Bawuah-Edusei calls for Solidarity (www.ghanaweb.com, accessed, 12/16/2009, 2007

[8] Ahadzie, D.K. A Model for Predicting the Performance of Project Managers in Mass House Building Projects in Ghana, PhD Thesis, University of Wolverhampton, UK, 2007

[9] Kwarteng, E. M (2007) Aftermath of Floods, Feature Article in Daily Graphic, June, 23 pp. 18

[10] Leedy, P. D and Ormrod, J. E Practical Research, Planning and Design, International Edition, 2005

[11] Braun V and Clarke, V Using Thematic Analysis in Psychology, Qualitative Research in Psychology, Vol. 3, pp. 77 -101, 2006

[12] Patton, M.Q Qualitative Evaluation and Research Methods, Second Edition, Sage, 1990

[13] Daily Graphic Builsa Assembly Calls for Supply of More Tents Sept. 20, pp. 21, 45, 2007

[14] Daily Graphic Floods Affect Five Bridges in Three Northern Regions Sept. 17 , pp. 16, 2007

[15] Daily Graphic, Floods Kill 8 in the Northern Region, Sept 10, pp. 1/3, 2007

[16] Daily graphic, Red Cross Gives Relief Items to Flood Victims, Dec. 18, pp. 48,2008 
[17] Daily Graphic, Spillage of Bagre Dam at Burkina Faso; NADMO Dispatches Rapid Response Team. Sept. $29^{\text {th }}$ pp. 21, 2009

[18] Daily Graphic Floods in Northern Region-Death Toll, 15, 140,000 Homeless Sept. $10^{\text {th }}$, pp.1,3, 2009

[19] Daily Graphic, MP Donates Roofing Sheets to Rainstorm Victims, June 9 pp. 21

[20] Daily Graphic, Rains- Worse Yet To Come-Says Meteorologist. June, 8, pp. $1 / 3,2005$

[21] Daily graphic, Committees Set Up To Manage Disaster, May 29, pp.27, 2006

[22] Daily graphic, Floods Destroy Property In Accra, April 7, pp 24, 2006

[23] Daily graphic, MPs Calls For More Resources For NADMO May 20 pp,13, 2006

[24] Daily Graphic, Engineers Blame Government for Floods. July, 14 pp. 18, 2007

[25] Daily Graphic, Flood Causes More Havoc- 31 Now Perishes In UER Sept. 20 pp. $1 / 3,2007$

[26] Daily Graphic, Flood Destructions in Northern Ghana-Causes and Solutions. Oct. 31, pp. 7/ 9, 2007

[27] Daily Graphic, Government to Spend C9bln on Dams and Water Works. June 10, pp. 40, 2007

[28] Daily Graphic, Accra Hosts Big Confab-In Search of Solution to Climate Change. Aug. 22, pp. 1 and 2, 2008

[29] Daily graphic, Floods Alert-Meteo Warns of Terrible Condition, April 3, pp. 1/ 3, 2008

[30] Daily graphic, Rapid Response Team to Deal with Floods; April 4, pp. 1/,3, 2008

[31] Daily Graphic, World Vision Assists Disaster Victims In Northern Ghana. $23^{\text {rd }}$ Sept pp. 20, 2008

[32] Daily Graphic, Flood Alert; Bagre Dam Opens Aug, 25, Pp. 1/ 3, 2008

[33] Daily Graphic, Government Inaction, Cause of Flood. Pp. 29. May 16, 2008

[34] Daily Graphic, Heavy Rains Affect Six Regions in the Northern Region. Sept. $29^{\text {th }}$ pp 14, 2009

[35] Daily Graphic, NADMO VRA On the Move to Prevent Disaster in Three Northern Regions Aug. 19, pp. 1/2., 2009

[36] Daily Graphic, Floods Imminent In 3 Northern Regions As Burkina Faso Spills Her Dams. Sept. 4, pp. 20, 2009

[37] Daily Graphic, Heavy Rains Floods Farms in Bawku Municipality. Sept.8, pp. 48, 2009

[38] Daily Graphic, Implications of the Floods in Northern Ghana. Sept.26, pp. 7, 2009

[39] Daily Graphic, 27 Flood Victims Receive Relief Items Sept. 24 pp. 42, 2009

[40] Daily Graphic, Floods Threaten Food Production in Northern Region. Sept.4 pp. 35, 2009 
[41] Daily Graphic, Daily graphic, No Deaths in Recent Floods-NADMO Sept.8, pp. 48, 2006

[42] Ghana News Agency, Don't Give up Farming Because of Flooding (www.Ghanaweb.com accessed, 12/16/2009, 2007

[43] Ghanaian times, Accra experiences floods, Sept. 1, pp. 10, 2007

[44] Ghanaian Times, 5 Die in Floods. July, 4, pp. 1/4, 2007

[45] Ghanaian Times, Flood Displaces 50,000 at Builsa. Sept. 18, pp. 1/ 4, 2007

[46] Ghanaian Times, Aowin- Suaman Flood Victims Get Building Inputs. Sept. 12 , pp. $1 / 3,2007$

[47] Ghanaian Times, MOFA Assesses Effects of Flooding on Farming. Oct. 7 pp. $1 / 3,2007$

[48] Ghanaian Times, More Problems for Flood Victims Sept. 20, pp. 1/3, 2007

[49] Ghanaian Times, N.R Considers Disaster Zone Status. Sept. 10 pp 1/3, 2007

[50] Ghanaian Times, Northern Citizens Bag C 153m for Home Oct. 2, pp. 1/3, 2007

[51] Ghanaian Times, SOS To Rebuild Homes of 2 Flood-Hit Communities Nov. 23 pp. 32, 2007

[52] Ghanaian Times, DCEs Begin Moving Relief Items. Oct.25 pp 1/32, 2007

[53] Ghanaian Times, Three Regions Declared Disaster Zones. Sept. 12 pp 1/3, 2007

[54] Daily Graphic Flood Destructions in Northern Ghana-Causes and Solutions, Oct. 29, pp. 23, 2007

[55] Strahler, A.H. and Strahler, A.N. Physical Geography: Science and Systems of the Human Environment, John Wiley and Sons, 1992

[56] The Ghanaian Times, The Rains and Accra Roads, June 20, pp.1, 2005

[57] The Ghanaian times, Parliament Wants NADMO Resourced May 22. pp. 15,2005

[58] UN Integrated Regional News Food Shortages Follows Drought, Floods (www.Ghanaweb.com, accessed 12/16/2009, 2007 